\title{
Influence of Performance Appraisal on Motivation of Public Secondary School Teachers in Gem-Sub County, Kenya
}

\author{
Alice Atieno Okoth \\ Oluoch Mercy Florah \\ University of Nairobi \\ Department of Business Administration
}

\begin{abstract}
Organizations that adopt an efficient and properly structured appraisal system are likely to impact on the motivation of its employees resulting in higher performance and attainment of an organizations goals and objectives. Many of these studies have been done in the public and private sectors, but very little has been done specifically on teacher performance appraisal and its influence on motivation of teachers in public secondary Schools in Gemsub county. The aim of the study was to establish the influence of performance appraisal on motivation of public secondary school teachers in Gem - Sub-county. Descriptive survey method was used. The target population for this study was446 teachers from public secondary schools in Gem SubCounty. Random sampling technique was used to select the sample of 103. Structured questionnaires were used to collect primary data. Regression analysis was used to determine the influence of teacher performance appraisal on motivation of teachers in public secondary schools in Gem Sub-county. The findings of the study showed that fairness in performance appraisal, performance appraisal feedback, performance rewards and performance goal setting had a positive and significant effect on teacher motivation in Gem sub-county. The study concludes that performance appraisal enhances teacher motivation. This study recommends that the government of Kenya though teachers service commission should continue employing performance appraisal mechanisms. Additionally, there are some human aspects of performance appraisal such as integrity and ethical values that enhances trust in appraisal process. This study therefore recommends that the government should adopt appraisal processes that incorporate integrity and ethical values that will ensure continuous trust in the appraisal process, adopt effective reward mechanisms and effective feedback policies. The study limited itself to teachers in public secondary schools. The researcher therefore recommends further research by academicians on teachers in other schools such as public primary, private primary and secondary schools; use other variable including organization commitment and job satisfaction. Moreover, more studies to be carried out to bring these to the fore since the subject of teacher motivation is important not only to the government but other stakeholders too.
\end{abstract}

Keywords: Performance Appraisal, Motivation, Public Secondary School Teachers, Gem-sub County

\subsection{Introduction}

An organization success and its subsequent productivity can be attained when the workforce undergo a continuous evaluation and appraisal. Employee's performance appraisal remains anon-stop audit of the performance. The process enables an organization to attain a competitive advantage over its competitors Obisi (2011). According to Armstrong (2009), the non-stop audit of performance is the responsibility of top managers and team leaders. This process leads to organizational effectiveness and efficiency. Performance measurements in educational institutions in the recent years have become a key issue in the strategic attainment of its goals and objectives to sustain competitiveness. Adoption of performance appraisal as a management tool in educational institutions enhances accountability and a guide to attainment of set goals and consequently improvement in performance Kenyatta, (2016). According to Midimo (2017) employee performance appraisal helps to develop employee so as to improve on their individual weaknesses to a more productive work ethic, provides corrective feedback on achievements and offers direction and support to performance improvement. It is used as a visible tool for employee accountability to the employer and the stake holders.

This study was anchored on two theories, the goal theory on motivation (Latham and Locke, 1979) and expectancy theory (Vroom, 1964).Human nature is psychologically attached to inspiration inwardly or outwardly to strive and attain organizational or personal goals and objectives with an attached expectation of rewards Bagga (2014). Goal setting impacts on an employee's productivity and work outcome. Goals for employees must be realistic as failure to attain the high target goals and expectations, is likely to discourage the employee leading to low morale and dissatisfaction Bett (2017). 
Low motivation index of teachers has a direct impact on teaching and learning output within the public high schools in Gem Sub-county which has been dismal. The poor performance is linked to low teacher morale, dissatisfaction, ineffectiveness, lack of; commitment and teacher effort, professional development and goal attainment, poor psychological fulfillment despite the review of their performance during the teacher performance appraisal and development exercise.

\subsubsection{The Concept of Performance Appraisal}

Michal (2015) defines performance appraisal as techniques used in an institution to evaluate the level of performance of their employees. This involves measuring of performance and proving them with feedback. Omayo (2016) defines performance appraisal a process of assessing the performance and progress of an instructor or of a group of instructors on a given job and his potential for future development. According to Kuvaas (2016) performance appraisal is a guided process of setting goals, reviewing the performance against the set goals, providing feedback on performance and planning on performance improvement. Performance appraisal consists of all formal procedures used in work organizations to evaluate personalities, contributions and potentials of employees. Organizations employ different methods to carry out performance appraisals. Teacher performance appraisals are conducted termly or yearly to evaluate progress against set goals .However this varies depending on the intention of the appraisal results Muhammad (2011).

Performance evaluation methods can be categorized into conventional methods which includes rating scales; numerical scales representing job performance of an individual employee, checklists; yes /no statements related to employee performance, behavior anchored rating scales ;noted good or undesirable behaviors that determine an employee's performance rating, field review method; observation and rating by someone outside your department, confidential reports by supervisors and cost accounting method; performance is rated on returns against investment Rhana (2014).

Performance appraisal has been acknowledged as a tool to manage performance and improve results Namudu (2015).The aim is not confined to measuring performance only but to align organization goals and objectives and personal teacher ambition and improve their teaching performance according to their student needs Elliot (2015).Performance appraisal process should be fair with clear goals set to be achieved, performance reviewed, provide feedback to the appraised and plan for performance improvement, to improve overall productivity,

\subsubsection{The Concept of Motivation}

Motivation is a drive that influences an individual to do something naturally and remains an established process management use that encourages individuals to perform better and offers employees motives founded on the unsatisfied need Armstrong (2009). Motivation stimulates people to action to accomplish desired goals. Motivation refers to the willingness, desire and drive to personally involve in productive service Guarjardo (2011). Motivation is viewed as intrinsic or extrinsic, and has a large influence on the human behavior Sinclair (2011). The intrinsic aspect includes personal pleasure, satisfaction and self-fulfillment, while the extrinsic aspect largely influenced through support of objects to elicit a motivated reaction. Individuals are motivated differently owing to what they perceive to be of interest that arouses changes in behavior, either from within or outside an individual Khan (2013).

Organizations can use different methods to manipulate employee motivation. Nonetheless, such practices bear both positive and negative implications. Case in point, giving rewards might inspire or discourage motivation. The implications are dependent on the reward type and the setting in which it is given Gottfried (1990). High teacher motivation will likely result to overall improved performance and also exhibit additional effort. Guarjardo (2011) opines that well motivated teachers will exhibit superior performance not just standard performance as portrayed by everyone else. Teachers are likely to strive to attain personal goals and professional development, increased efforts, observe professional conduct, initiative and creativity, effectiveness in teaching, psychological fulfillment ,commitment and longevity in the profession

\subsubsection{Teachers in Public Secondary Schools in Gem- Sub County}

The 2012 Basic Education Act (2012) states that a public secondary school is a state owned school and should admit a minimum of ten students receiving regular instructions with a formalized and approved curriculum of study. Public Secondary Schools in Kenya are government funded through the Free Secondary Education since 2013. A Parents Association (PA) and a Board of Management (BOM) manages the schools. Public Secondary Schools are grouped as National Schools, Extra county Schools, County Schools, Sub-County Schools and Special needs Schools. Public Secondary Schools in Kenya follows the 8-4-4 system. There are performance appraisal practices adopted in Gem sub county public secondary schools to plan, asses and provide feedback regarding individual teacher performance. Owiye (2016) observes that little has been achieved to show for the teacher performance appraisal practices in relation to the effect it has in teacher motivation. 
Teacher motivation in these schools has been wanting, characterized by high staff turnover, Lack of teacher commitment and teacher dissatisfaction, absenteeism, ineffective teaching methods and lack of teacher professional development.

\subsection{Research Objective}

The objective of the study was to determine the role of teacher performance appraisal on motivation within public secondary schools in Gem sub-county.

\subsection{Research Problem}

Organizations that adopt an efficient and properly structured appraisal system are likely to impact on the motivation of its employees resulting in higher performance and attainment of an organizations goals and objectives. Muruiki (2016) opines that effective performance assessment is a primary feature in the general function of the HRM. Individuals in different organizations are motivated to meet set objectives and goals if their behavior and activities towards attainment of the goal will result to a reward that which, is of value and creates a satisfaction of something important that they require. The level of an organization attainment of its goals and objectives are directly linked to the level of motivation the employee has Mwakindimi (2018).

Research findings by Swank \& Kamphorst (2015), Kumari (2014), Ushus \& Johnson (2015), Akpotu \& Oghvubu (2014), Suresh (2013) and Muhammad, et.al (2011) all support a strong existing relationship between performance appraisal and motivation which leads to a positive outcome in the teaching and learning process. However Guarjardo 2011) opines that it is not automatic that PA appraisal will definitely lead to motivation of employees. The study found out that environmental factors within the teaching and learning process also affects the motivation of a teacher.

Teacher commitment and longevity in the profession has however declined. Professional development amongst teachers is noted to be slow with some opting for different professions. Ineffective teaching methods and lack of creativity to infuse modern teaching methods and use of technology has been attributed to little motivation incentives that arise from the performance appraisal process Ojina (2017) which are also experienced by Public secondary school teachers in Gem sub-county.

Various Global, regional and local empirical research undertaken have established the link between performance appraisal and employee motivation. Namudu (2005) on staff performance appraisal systems and their effect on teachers' motivation at Agha Khan Schools in Uganda noted a significant relationship between schools based criteria of evaluation and level of empowerment that teachers felt. Muriuki (2018) conducted a study on the implication of appraisals motivation, at the Ministry of East African Community, Labour and Social Protection and concluded that adoption of employee performance review system motivated the employees. It further recommends that involvement of all the employees in the appraisal process would necessitate a greater success that involvement of only a few people.

Locally, such findings are attributed to the studies by Githui (2018) used regression tool to examine the influence of employee assessment method on employee motivation at The Lions Eye Hospital. The researcher discovered that there exists a positive correlation between employee high morale and performance appraisal. Ndegwa (2014) conducted a research to establish the implications of performance appraisal motivation on staff performance. The study focused on employees from the National Housing Cooperation. He concluded that the adoption of an effective and a fair system in assessment of employee performance is highly essential for motivation of employees at NHC. Owiye (2016) conducted a study on appraisal practices in government secondary schools in Ugunja. Research findings demonstrated that performance appraisal system that was perceived as fair and had an impact and valued reward motivated the teacher in return high performance was realized in the work output.

Many of these studies have been done in the public and private sectors, but very little has been done specifically on teacher performance appraisal and its influence on motivation of teachers in public secondary Schools in Gem sub county. The aim of the study is to establish the influence of performance appraisal on motivation of public secondary school teachers in Gem - Sub-county. Thus the research sought to answer the question; what is the influence of performance appraisal on motivation of teachers in Gem sub-county?

\subsection{Literature Review}

\section{Performance Appraisal and Motivation}

PA is used by organizations as a technique to influence desirable behaviors of employees to ensure they attain organizational and individual productivity. The assessment of employees regular performance leads to motivation .The system used to rate and gauge employees performance should in cooperate all the dimensions that leads to accuracy and effectiveness to achieve the desired results Chapoda (2014). 
Employees will be motivated if they perceive the performance appraisal system to be accurate without any bias, is all inclusive with the relevant goals set that match their job descriptions, when there is clear feedback on the appraisal process and the outcome discussed by the supervisor and when appropriate rewards are offered to match the achievement and the productivity levels of an employee. The aim of the performance appraisal should bet measure accurately and effectively an employee's performance anchored on fairness. Fairness of performance appraisal has been found to have a significant impact on motivation. Suresh (2013) concur that if the provision of a precise appraisal method is deemed biased, it might result into negative results. It is also likely that an accurate evaluation system that is viewed as fair might cause negative results. Impartiality should be incorporated's inceitis a crucial value. According to Namuddu (2005) in the study of performance appraisal on motivation of teachers in Agha Khan Schools, found out that notions on bias have significant effect on an organization and the teacher as well. It also observed that performance appraisal influences the motivation of teachers. A study conducted by Ushus and Johnson (2015) in Kerala India indicate a significant link between fairness in the appraisal strategy and employee motivation. The study also established that there exists a negative association employee work performance and motivation in the tourism sector. High work performance exhibited was due to performance appraisal fairness and lack of motivation impacts negatively on the work output. Cheng (2016) defines goal setting as a structured and a formal process that involves an employee and an employer in setting quantitative performance standards. Cheng \& low (2016) studied the impact of goal setting on employee effectiveness and motivation and the results indicated that overall effectiveness is achieved when goals are built around individuals who are motivated to achieve them.

Singh \& Rhana (2014) make a remarkable finding that a significant correlation exists between appraisal strategies and motivation of teachers in professional institutions and assessment of their performance. Additionally, the research proves that goal setting and feedback were predictors of teachers' motivation to provide positive educational outcomes A performance assessment was conducted by Akpotu (2014) across secondary schools in Nigeria. The study gathered viewpoints from students and evaluated the role of the learners in the evaluation of their teachers in the developed countries. The study results showed that teachers were competent and dedicated and there was need to have a more inclusive performance appraisal goal setting strategy in teacher evaluation which impacts on their motivation levels in Nigeria. A research by Muhammad (2011) on performance review method for teachers found that teacher performance appraisal plays a fundamental role in shaping the behavior of teachers that impact on their general performance. It concludes that any organization needs employees that will do jobs that are centered on goals and objectives that they are involved in and this is attainable only if the employees are well motivated.

Swank (2015), in his research on the role of performance appraisal in motivating employees, developed a model in which it is aimed at an employee's assessment through providing feedback. It recommends that the model be used by senior managers in performance assessments and provision of feedback to employees. The concept aims at influencing the workers behavior and self-perception and their abilities to individually appraise themselves. There is a strong correlation between supervisor appraisal feedback and motivation of individual teacher to perform the task and have above average performance outcome.

A study by Ndegwa (2014) on the implications of assessing performance and employee motivation at NHC concluded that performance appraisal was a crucial element in staff appraisal of employees and overall productivity. Furthermore, feedback communicated to employees significantly boosted their motivation levels. It revealed that PA would be more effective if it was conducted on a more regular basis and feedback discussed to improve on performance. Oluoch (2017) conducted a survey to determine the correlation between job satisfaction, appraisal methods, and performance assessment using descriptive statistics and Pearson correlation coefficient. The study concluded that performance appraisal influences motivation, employee working relationship and employee happiness to a moderate extent and subsequently job satisfaction. In addition the performance appraisal feedback should be done objectively so as to be perceived to be fair by employees for it to meaningfully impact behavior and lead to high productivity.

Webster (2018) defines rewards as tangible and non -tangible incentives given to an employee for a service done to the organization. This is done to encourage the continuity of the good behavior, attract and retain high caliber employees in the organization. Baskar, et al (2015)in the study of impact of rewards and recognition on employee motivation, opines that there is a significant direct positive relationship between rewards and motivation of employees. It further notes that better rewards results in greater levels of individual and organizational productivity. Rewards given have different motivational impacts to different people thus different strategies should be adopted and not one reward to be assumed will elicit the desirable behavior to all employees. Khalid (2011) study on impact of rewards and motivation on job satisfaction in the water utility industry, notes that rewards have a positive significant influence on motivation which directly influences the productivity levels of individual employees. 
A study by Kathure (2014) on influence of non-financial rewards on employee motivation and commitment draws a similar conclusion with Lera (2012) in the study of the perceived influence of performance based reward system and employee motivation at Barclays Bank Kenya ; tangible or intangible rewards directly positively influences the motivation of employees to achieve greater results

\subsection{Research Methodology}

\subsubsection{Research Design}

Descriptive survey method was used. A descriptive survey design is a scientific research method that studies the behaviour and occurrences of a phenomenon without any alteration at all. The type of research design mostly focuses on ' what' as the research subject matter. Ojina (2017) notes that descriptive research aims to illustrate an occurrence therefore survey and observation tools are used to collect data. The research design purposes to describe what exists in relation to the dependent and independent variable .It aims at collecting data without alteration whatsoever of the context of study.

\section{Population}

Table 1: Population Distribution

\begin{tabular}{|l|l|l|l|}
\hline School level & No. of Schools & Teachers & Percentage \\
\hline National & 1 & 44 & $10 \%$ \\
\hline Extra county & 2 & 59 & $13.2 \%$ \\
\hline County & 6 & 116 & $26 \%$ \\
\hline Sub-County & 21 & 227 & $50.8 \%$ \\
\hline Total & 30 & 446 & $100 \%$ \\
\hline
\end{tabular}

\subsubsection{Sample Size}

A population sample is a fraction of the entire population that will be studied. The result of the portion identified is then used to generalize the outcome of the study. A stratified sampling method was used by the researcher. Ojina (2017) notes that a sample size that has been identified should be an adequate representation of the total population and that it should consider the resources to be used in terms of money and available time of the researcher to collect data as it was in this case.

\subsubsection{Sample Design}

Teachers in public secondary schools in Gem sub-county were use dissembling unit for the research. 103 instructors were sampled out of 446 using random sampling technique which was 23 percent for each category.

Table 2: Sampling Frame

\begin{tabular}{|l|l|l|l|l|}
\hline School level & No. of Schools. & Teachers & Sample & Percentage \\
National & 1 & 44 & 10 & $23 \%$ \\
\hline Extra- county & 2 & 59 & 14 & $23 \%$ \\
\hline County & 6 & 116 & 27 & $23 \%$ \\
\hline Sub-county & 21 & 227 & 52 & $23 \%$ \\
\hline Total & 30 & 446 & 103 & $23 \%$ \\
\hline
\end{tabular}

\subsubsection{Data Collection}

The researcher used primary data collected through a structured questionnaire. The question included both open and close ended questions. The respondents were expected to provide answers to the open ended questions. In the case of closed ended questions provide a greater uniformity of responses and were easily processed than open ended ones. The questionnaire was split into two sections. The initial section asked questions concerning the general responded information. The second section established the influence of the PA process on employee motivation. A five-point Likert- scale and rankings was used to reflect the appropriate levels of measurement necessary for statistical analysis.

\subsubsection{Data Analysis}

Descriptive and inferential statistics indicating the nature of data collected was provided.

Descriptive statistics of interest were mean which provided the measure of central tendency and standard deviation which showed the dispersion of dataset relative to its mean. Results were then presented using tables to make them easier to understand and interpret. Regression analysis was used to provide inferential statistics. Correlation coefficient provided the strength and direction of relationship between the dependent and independent variables. 
Overall significance of the models was evaluated using the F-statistics and p-values while significance of parameter estimates were evaluated using t-statistics and p-values. Study was modeled along the multiple linear regressions below;

Where,

$$
y=\beta_{0}+\beta_{1} x_{1}+\beta_{2} x_{2}+\beta_{3} x_{3}+\beta_{4} x_{4}+\varepsilon
$$

$\beta_{0}=$ Constant

$\beta_{1}-\beta_{4}=$ Estimates

$\mathrm{X}_{1}=$ Fairness in performance appraisal

$\mathrm{X}_{2}=$ Performance appraisal feedback

$\mathrm{X}_{3}=$ Performance goal setting

$\mathrm{X}_{4}=$ Performance Rewards

$\varepsilon=$ Error

\subsection{Data Analysis, Findings and Discussions}

\subsubsection{Performance Appraisal Dimensions}

This section contains descriptive statistics for all the variables used in this study.

\section{Fairness in Performance Appraisal}

Respondents were asked to mark the extent to which they strongly agree or disagree with measures of fairness in performance appraisal. Respondents were subjected to 5 statements that were measuring fairness in performance appraisal using a five likert-scale. Analyses of their responses are provided in the table below:

Table 3 Fairness in Performance Appraisal

\begin{tabular}{|l|l|l|}
\hline & Mean & Std. Deviation \\
\hline My goals are linked to the overall school goals & 4.1042 & 0.77842 \\
\hline The process is transparent with no bias & 4.3333 & 0.78098 \\
\hline My supervisor monitors and guides me continuously to achieve the goals set. & 3.8958 & 1.11545 \\
\hline $\begin{array}{l}\text { My performance expectations is usually defined in my individual work plan and job } \\
\text { description }\end{array}$ & 3.9375 & 1.06003 \\
\hline I am involved in planning of my performance & 4.2500 & 0.88726 \\
\hline & & \\
\hline
\end{tabular}

From the above descriptive results, given the small SD of .778 42, majority of respondents strongly agreed that their individual goals are linked to the overall school goals with a mean of 4.1042. On whether appraisal process is transparent with no bias, still majority of respondents strongly agreed that the process is transparent with no bias (mean 4.3333 and SD of .78098). Moreover, respondents strongly agreed that they are involved in performance planning. However, there was a considerable dispersion from means about continuous guidance and monitoring of employee performance by their supervisors. In addition, employees did not agree that performance expectations are usually defined in their individual work plan and job description. These results on imply that employees consider performance appraisal to be fair, however, supervisors need to continuously guide the employees and performance expectations should match work plan and job description.

\subsubsection{Performance Appraisal Feedback}

Targeted teachers were asked to required express the extent to which they strongly agree or disagree with measures of performance appraisal feedback. Respondents were subjected to 4 statements that were measuring performance appraisal feedback using a five likert-scale. Analyses of their responses showed that they agreed that they receive performance appraisal feedback as indicated that are provided in the table below:

Table 4 : Performance Appraisal Feedback

\begin{tabular}{|l|l|l|}
\hline & Mean & Std. Deviation \\
\hline $\begin{array}{l}\text { My supervisor holds a performance review meeting to discuss my performance } \\
\text { outcome }\end{array}$ & 3.5625 & 1.31935 \\
\hline I am provided with feedback based on factual evidence on my performance & 3.6667 & 1.22619 \\
\hline My performance feedback impacts on my overall performance & 3.8333 & 1.19098 \\
\hline My performance feedback motivates me to improve on my performance & 3.8333 & 1.20872 \\
\hline
\end{tabular}

From the above table, all measures of performance appraisal feedback recorded large standard deviations from their means. This shows that some respondents strongly agreed and some strongly disagreed about performance feedback 44 
while majority were indifferent. This result imply that majority of supervisors do not share performance feedback with their employees. Given the fact that continuous feedback plays a significant role in the appraisal process of an organization, supervisors need to be proactive and agile to reap the benefits of continuous feedback

\section{Involvement in Goal Setting}

On goal setting, teachers were asked to indicate the extent to which they strongly agree or disagree with being involved in performance goal setting. Respondents were subjected to 3 statements that were measuring involvement in performance goal setting using a five likert-scale. Analyses of their responses showed that they agreed that they get involved in performance goal setting as indicated that are provided in the table below:

Table 5: Involvement in Goal Setting

\begin{tabular}{lll}
\hline & Mean & Std. Deviation \\
\hline I am involved in goal setting & 3.9375 & 1.09944 \\
I have the right tools to achieve my goals & 3.6458 & 1.19377 \\
My organizational goals are in line with my personal goals. & 3.8333 & 0.99645 \\
\hline
\end{tabular}

Another important indicator of the usefulness of an appraisal process is how well the goals set align with the strategic and operational objectives of the organization. With a standard deviation of 1 , the findings indicate that $68 \%$ of the respondents agreed that they are involved in goal setting. Given the important role goal setting plays in performance appraisal, performance management of teachers should be viewed in their organizations as a business-critical process and not as an HR process.

\subsubsection{Performance Rewards}

Respondents were asked to express the extent to which they strongly agree or disagree with performance reward measures. Respondents were subjected to 4 statements that measured performance reward using a five likert-scale. Analyses of their responses showed that they agreed on the element of performance reward as indicated in the table below:

\section{Table 6 : Performance Rewards}

\begin{tabular}{lll}
\hline & Mean & Std. Deviation \\
\hline I am involved in determining my reward & 3.1458 & 1.39893 \\
My school has a framework to reward excellent performance & 3.2292 & 1.34068 \\
My performance is linked to reward and compensation & 2.7500 & 1.36054 \\
The rewards offered motivates me to work hard and enhances my productivity & 3.0208 & 1.50869 \\
\hline
\end{tabular}

Employees are not inherently born with the desire to come to work and put in their maximum. Reward systems promote fairness and equity by rewarded employees according to their contribution and effort to the organization. This study established that teachers in Gem sub-county were indifferent about reward for their performance. According to the results above majority of respondents disagreed that their reward are linked to their performance. This implies that employees are not rewarded for putting in more effort and even if they are rewarded, the rewards are inadequate and not related to their work input.

\section{1.5 Influence of Performance Appraisal on Employee Motivation}

Regression analysis was employed to determine effect of teacher performance appraisal and motivation in public secondary schools in Gem Sub-county. A multiple linear regression was carried out in order to establish the effect of performance appraisal on Motivation and the regression estimates are presented as shown in the table below:

Table 4.7 For performance appraisal on employee motivatiion

\begin{tabular}{|c|c|c|c|c|c|c|}
\hline \multicolumn{7}{|c|}{ Coefficients $^{\mathbf{a}}$} \\
\hline \multicolumn{2}{|c|}{ Model } & \multicolumn{2}{|c|}{ Unstandardized Coefficients } & \multirow{2}{*}{$\begin{array}{l}\text { Standardized } \\
\text { Coefficients } \\
\text { Beta }\end{array}$} & \multirow[t]{2}{*}{$\mathrm{T}$} & \multirow[t]{2}{*}{ Sig. } \\
\hline & & B & Std. Error & & & \\
\hline \multirow{5}{*}{1} & (Constant) & 1.898 & .501 & & 3.788 & .000 \\
\hline & Fairness & .341 & .217 & .370 & 1.569 & .124 \\
\hline & Feedback & -.020 & .156 & -.035 & -.129 & .898 \\
\hline & Goal setting & .012 & .141 & .018 & .088 & .930 \\
\hline & Rewards & .227 & .082 & .424 & 2.780 & .008 \\
\hline
\end{tabular}

Dependent Variable: Motivation

Source Researcher Analysis (2019) 
The multiple-linear regression model between performance appraisal and Motivation therefore is as follows:

\section{Motivation $=1.898+0.341$ Fairness -0.20 Feedback +0.12 Goalsetting +0.227 Rewards}

From the coefficient estimates above, the findings indicate that appraisal feedback positively influence employee motivation, goal setting positively influence employee motivation and similarly rewards positively influence employee motivation. However, appraisal feedback had a negative influence on employee motivation.

To show whether the linear regression model above fits the data significantly, ANOVA was computed as provided in Table below:

Table 4.8 ANOVA $^{\mathrm{a}}$ for performance appraisal and employee motivation

\begin{tabular}{|ll|l|l|l|l|l|}
\hline Model & & Sum of Squares & df & Mean Square & F & Sig. \\
\hline \multirow{2}{*}{1} & Regression & 9.433 & 4 & 2.358 & 10.206 & $.000^{\mathrm{b}}$ \\
& Residual & 9.936 & 43 & .231 & & \\
& Total & 19.368 & 83 & & & \\
\hline
\end{tabular}

a. Dependent Variable: Motivation

b. Predictors: (Constant), Rewards, Fairness, Goal setting, Feedback

The ANOVA table shows that linear regression model does significantly fits the data with $\mathrm{F}(1,83)=10.206$ at $\mathrm{p}<.05$ $(\mathrm{p}=.000)$. This means that the independent variable performance appraisal has statistically significant influence on motivation of teachers in Gem sub-county.

In order to establish the proportion of the variance in the dependent variable (motivation) that is predictable from the independent variable (appraisal fairness), coefficient of determination was establish as shown in the table below;

\begin{tabular}{|l|l|l|l|l|}
\hline \multicolumn{4}{|l|}{ Model Summary } \\
\hline Model & $\mathrm{R}$ & R Square & $\begin{array}{l}\text { Adjusted R } \\
\text { Square }\end{array}$ & $\begin{array}{l}\text { Std. Error of the } \\
\text { Estimate }\end{array}$ \\
\hline 1 & $.798^{\mathrm{a}}$ & .636 & .619 & .54354 \\
\hline \multicolumn{5}{|l|}{ a. Predictors: (Constant), Rewards, Fairness, Goal setting, Feedback } \\
\hline
\end{tabular}

The model explains up to $63.6 \%\left(\mathrm{R}^{2}=.636\right)$ of the variance in the outcome (motivation). This means that the independent variables have strong influence on motivation of teachers.

Analysis of the significance of performance appraisal factors on employee motivation indicated that only performance reward had a positive and statistically significant influence on employee motivation.

\section{Discussion of Findings}

This study has established that fairness in performance appraisal had a positive impact on teacher motivation in Gem sub-county. Specifically, results of this study demonstrate that a $1 \%$ improvement in fairness in appraisal will cause a $0.341 \%$ increase in teacher motivation. This finding imply that, other things held constant, when individual teacher's goals are linked to the school objectives, perceived bias in appraisal process are minimized, there is established collaboration between the teacher and the supervisor, then the teacher will be greatly motivated. Importantly, this finding corroborates those of Namuddu(2005), Suresh (2013) and Ushusand Johnson(2015) who demonstrated that fairness of performance appraisal influenced employee motivation.

This study has determined that appraisal feedback has a negative result on teacher motivation in Gem sub-county. Specifically, results of this study showed that a $1 \%$ improvement in performance appraisal feedback will de-motivate employees by $0.20 \%$. This finding contradict that of Ndegwa(2014) who found out that feedback communicated to employees significantly boosted their motivation levels. The plausible explanation for this outcome is that supervisors may not be providing performance feedback to their employees and even if they did, the supervisors may not be effectively giving performance feedback. Given the fact that continuous feedback plays a significant role in the appraisal process of an organization, supervisors need to be proactive and agile to reap the benefits of continuous feedback.

This study has established that that Performance rewards has a positive and significant effect on teacher motivation in Gem sub-county. Specifically, results of this study showed that a $1 \%$ improvement in performance appraisal feedback will cause a $0.227 \%$ increase in teacher motivation. 
Generally, motivation relies on three factors; desire to receive a reward, the notion that extra input will result into more productivity and the employee's belief that a more beneficial result will occur. Hence, the rewards offered motivate the teachers to work hard and enhances their productivity. This finding is in tandem with those of Giancola (2011) and (Beer and Walton, 2014) whose study concluded reward motivates employees.

Finally, this study has established that that Performance goal setting has a positive association with teacher motivation in Gem sub-county. Specifically, results of this study showed that a $1 \%$ improvement in performance appraisal feedback will cause a $0.12 \%$ increase in teacher motivation. This result implies that if teachers are involved in setting their performance goals, are given the right tools to execute their functions, then teachers are bound to be motivated to perform better and achieve their employers expectations. This finding confirms those of Cheng (2016) and Singh \& Rhana(2014) who showed that goal setting were predictors of teachers' motivation to provide positive educational outcomes.

\subsection{Summary of Findings}

This paper analyzed the theoretical predictions of teacher performance appraisal on their motivation. The general goal of the study was to establish the influence of performance appraisal on employee motivation using a survey of public secondary school teachers. The effect of PA on teacher motivation was examined based on components of performance appraisal whereby a simple linear regression was run to test the objectives of the study on each of the components of performance appraisal.

The results of the study indicated that the response rate was at $81.55 \%$ which was adopted as confident range to make conclusive remarks and therefore good for the study. Majority of the respondents had a work experience of less than 5 years which was at $64.6 \%$ and those between 6 to 12 years being $22.9 \%$ which indicate that the majority of the teachers were averagely young people in the profession. In Job group category entrant level employees make up for $43.8 \%$ while lower level employees make up for $50 \%$ of the respondents which explains that majority of the respondents did not have senior management roles in administering the performance appraisal as supervisors but appraises. On level of education qualification $40 \%$ were degree holders which indicate that the respondents are competent enough to carry out their professional duties.

The study results to examine fairness in performance appraisal indicate that $1 \%$ improvement in fairness in appraisal will cause a $0.341 \%$ increase in teacher motivation. This study also has established that that Performance rewards has a positive and significant effect on teacher motivation in Gem sub-county. Specifically, results of this study showed that a $1 \%$ improvement in performance appraisal rewards will cause a $0.227 \%$ increase in teacher motivation. In addition inclusive goal setting has been noted by $68 \%$ of the respondents to significantly influence on motivation and a $1 \%$ increase in inclusive goal setting will result to a $0.12 \%$ increase in motivation. This result implies that if teachers are involved in setting their performance goals, are given the right tools to execute their functions, then teachers are bound to be motivated to perform better and achieve their employers expectations.

From the multiple regression estimates, this study has established that fairness in performance appraisal has a positive effect on teacher motivation in Gem sub-county. Secondly, this study has determined that performance appraisal feedback has a negative influence on teacher motivation in Gem sub-county. Thirdly, this study has established that that Performance rewards has a positive and significant effect on teacher motivation in Gem sub-county. Finally, this study has established that that Performance goal setting has a positive influence on teacher motivation in Gem sub-county.

\subsection{Conclusion}

PA is o considered one of the founding factors for employee motivation (Bagul, 2014). The performance appraisal cycle consists of established performance standards, a method of determining individual performance, comparison against standards and an evaluation of performance based on the comparison (Mishra, 2013). Findings on appraisal fairness, goal setting and rewards conform to theoretical and empirical findings. Of the three only performance rewards had significant influence. On the other hand, performance appraisal feedback was found to have a negative association with employee motivation.

Similarly, Shaw et al. (2008) argues that a well implemented performance appraisal system cannot afford to neglect any constituency and has to show all- round performance. However, on the negative side, receiving feedback from multiple sources can be intimidating, threatening, and expensive and time consuming (Shaw et al., 2008). This study therefore concludes that; that performance appraisal enhances teacher motivation.

\subsection{Recommendations for Policy and Practice}

Based on the findings of the study, this study recommends that the government of Kenya though teachers service commission should continue employing performance appraisal mechanisms. Additionally, there are some human aspects of performance appraisal as integrity and ethical values that enhances trust in appraisal process. 
This study therefore recommends that the government should adopt appraisal processes that incorporate integrity and ethical values that will ensure continuous trust in the appraisal process. Ministry of Education through TSC should adopt effective policies and mechanisms to ensure the rewards given to the teacher match their input which will lead to high motivation levels. Feedback channels adopted by the appraisal supervisors should also be effective and not punitive or intimidating to the teachers. Moreover, this study may be used as a source of reference for improving employees' performance and also to aid in further research through the gaps identified.

\subsection{Areas for Further Research}

The study limited itself to teachers in public secondary schools within Gem - Sub County. The researcher therefore recommends further research by academicians on teachers from other school such as public primary, private primary and secondary schools. In additions, it is the belief of the researcher that there are other factors that affect motivation apart from performance appraisal. It is therefore recommended that more studies to be carried out to bring these to the fore since the subject of teacher motivation is important not only to the government but other stakeholders too. The study also adopted a cross-sectional approach as the research design and it is recommended that a longitudinal approach in further research to determine the variables studied. Lastly this study limited itself to motivation as the dependent variable, the study recommends testing other variables influenced by PA as job satisfaction and organization commitment.

\section{References}

Aggarwal, A.\& Thakur G. S. (2013).Techniques of performance appraisal-A Review.International Journal of Engineering and Advanced Technology (IJEAT), 2 (3), 10-15.

Akpotu, N. E.(2014) Performance appraisal of the Nigerian secondary school teachers: The students perspectives . International studies in educational adminstration. 32(3), 44-54

Armstrong, M. (2009).A handbook of human resource management (11th Edition).

Bagga, S. \&Parijat, P. (2014). Victor Vroom's Expectancy Theory of Motivation: An Evaluation. International Research Journal of Business and Management 7(9) 1-7

Bagul, B. D. (2014) Study of employee's performance appraisal system. Journal For Humanity and English Language, $1(2), 20-24$

Beer, M. \& Walton, R. E. (2014). Reward Systems and the Role of Compensation. In J. G. Searle, Manage people, not personal (p. 17). Boston: Harvard Business Review

Bretz, R. D. \& Judge, T. A. (1994). The role of human resource systems in job applicant decision processes. Journal of Management, 2(1) 48-56.

Chaponda, N. C. (2014). Effect of performance appraisal systems on Employee motivation in slum based organization in Nairobi. Unpublished MBA paper.

Elliot, K. (2015). Teacher performance appraisal: More about performance or Development https// ro.ecu. edu .au >cgi

Giancola, F. (2011).Examining the job itself as a source of Employee Motivation. Compensation and Benefits Review , Vol. 43, Issue 1, pg. 23-29.

Gottfried, A. E. (1990). Academic intrinsic motivation in young elementary school children.Journal of Educational Psychology, 82(3)213-224

Gottfried, A. E., Fleming, J. S., \& Gottfried, A. W. (2001). Continuity of academic intrinsic motivation from childhood through late adolescence: A longitudinal study. Journal of Educational Psychology, 93(1) 114-123

Guajardo, J. (2011). Teacher Motivation: Theoretical Framework, Situation Analysis of Save the Children Country Offices, and Recommended Strategies Report.

Jency, S. (2016).720 Degree Performance Appraisal: An Emerging Technique, International Journal of Informative \& Futuristic Research, 3(8), 15-27

Khan, M. (2013).The role of performance appraisal system on employee motivation.IOSR Journal of Business and Management 8(4) 66-83

Kisang F. \&Kirai M. (2016).Effects of performance appraisal on employee motivation in commercial banks: a case of equity bank, Kenya. The Strategic Journal of Business and Change Management 3(4)29-41

Kumari, N. (2014). Using performance appraisal as an effective tool for motivating the employees performance: A live Study. Manav Rachna International University.

Kuvaas, G. (2016). Performance appraisal satisfaction and employee outcomes : mediating and moderating roles on work motivation. The international journal of Human Resource Management, 17(3), 504-522

Latham, G and Locke, R (2004) Goal setting - a motivational technique that works, Organizational Dynamics, autumn. London: Kogan Page. 
Midimo, L. (2014).Teachers response to performance appraisal; the case of secondary school teachers in Nyeri County.Unpublished MBA Project

Midimo, L. (2017). Teachers' response to appraisals; the case of secondary schools in Nyeri County.Unpublished MBA project.

Mishra, L. (2013).A Research Study on Employee Appraisal System Case of Hong Kong and Shanghai Banking Corporation (Hsbc) Bank.International Journal of Business and Management Invention, 2(2) 60-67

Mugenda, O. M. \&Mugenda, A. G.(2003), Research Methods, Qualitative andQuantitative Approaches, Nairobi Act Press.Newstrom.

Muhammad, I. R., Hassan D. A., Saira Y. \&Amna N. (2011). A critical analysis of performance appraisal system for teachers in public sector universities of Pakistan: A case study of the Islamia University of Bahawalpur (IUB). African Journal of Business Management, 5(9), 3735-3744

Mukhopadhyay K. (2015)360-Degree Appraisal - A Performance Assessment Tool: https://www.researchgate.net

Muriuki, C.W. (2016). Effect of performance appraisal on employee motivation at ministry of East African community, labour and social protection. Unpublished MBA project.

Mwakidimi, D. (2018). A human resource perspective of goal setting on employee performance and job satisfaction: the case of crown paints Unpublished MBA Project.

Namuddu, J. (2005). Staff appraisal systems and teacher performance at Aga khan schools in kampala district .Unpublished MBA project.

Obisi, C. (2011). Employee performance appraisal and its implication for individual and organizational growth.Australian Journal of Business and Management Research, 2(9) $92-97$

Ofojebe, W. N. \&Ifeoma, E. (2014).Management by Objectives (MBO) Imperatives for Transforming Higher Education for a Globalised World. Journal of International Education and Leadership 4(2) 114-121.

Ojina, O. (2017). Impact of perceived influence of ICT adoption on teacher performance in public secondary schools in Emuhaya Sub- County.Unpublished MBA project

Omayo, B. S. (2016) Influence of appraisal systems that head teachers use on performance of secondary school teachers in Borabu District in Kenya. Unpublished MBA project.

Owiye, B. A. (2013). A survey of performance appraisal practices in public secondary schools in Ugunja District, KENYA. Unpublished MBA project.

Rhana, S. \& Singh P. S. (2014).Impact of performance appraisal on the motivation of teachers of professional institutions in Dehradun city. Journal of International Education and Leadership, 4(1)161-232

Shaw, J. D., Delery, J. E., Jenkins, G. D., \& Gupta, N. (2008).An organization-level analysis of voluntary and involuntary turnover. Academy of Management Journal, 41, 511-525.

Suresh, P. (2013). A study on performance appraisal of automobile industries, at Chennai, Tamilnadu.International Journal of Marketing, Financial Services \& Management Research, 2 (5)2277-3622

Swank, H. O. \&Kamphorst, J.A. (2018).The role of performance appraisal in motivating employees.Journal of economics and management strategy 27(1) 251-269

Thomson, T. (2012).Management by Objectives (MBO) imperatives for transforming higher education for a globalized world.Journal of International Education and Leadership, 3(1)16-22

World Bank Report (2008). Education in Sub-Saharan African policies of adjustment, revitalization and expansion, World Bank, Washington, DC.

Zondo, R.W. (2018). The influence of a 360-degree performance appraisal on labour productivity in an automotive manufacturing organization.South African Journal of Economic and Management Sciences, 21(1), 20-46. 